\title{
Systemic sclerosis presenting as digital ulceration in an elderly female
}

\author{
Martin E Winstanley (ㅈ, ${ }^{1}$ Amy C Carmichael, ${ }^{2}$ Ella Harrison-Hansley ${ }^{3}$
}

${ }^{1}$ Nevill Hall Hospital, Abergavenny, UK ${ }^{2}$ Hanham Health, Bristol, UK ${ }^{3}$ Prince Charles Hospital, Merthyr Tyddfil, UK

\section{Correspondence to} Dr Martin E Winstanley; martin.winstanley@uhbw. nhs.uk

Accepted 28 September 2021

\section{DESCRIPTION}

An 80-year-old female presented to the emergency department with a 3 -week history of worsening digital discolouration. She explained that her right little finger was affected first, turning blue and then blistering at the tip (figure 1). Her left index finger tip subsequently turned black, and the changes were spreading proximally at the time of presentation (figure 2). For several years, she had noted digital changes consistent with Raynaud's phenomenon, but her symptoms were manageable with lifestyle modification and she had not previously sought medical attention. On examination, her left index finger was dusky and cool to touch, and there was evidence of sclerodactyly and finger pad telangiectasia. She was admitted for inpatient investigation of her digital ulcers. Serology revealed anti-centromere antibodies, and echocardiography revealed pulmonary hypertension. These findings supported a diagnosis of limited systemic sclerosis. In general, patients with late-onset systemic sclerosis (over 75 years) suffer more frequently with the limited subtype, more frequently with pulmonary hypertension and less frequently with digital ulcers. ${ }^{1}$

The digital ulcers seen in this case were ischaemic complications of systemic sclerosis. Microvascular

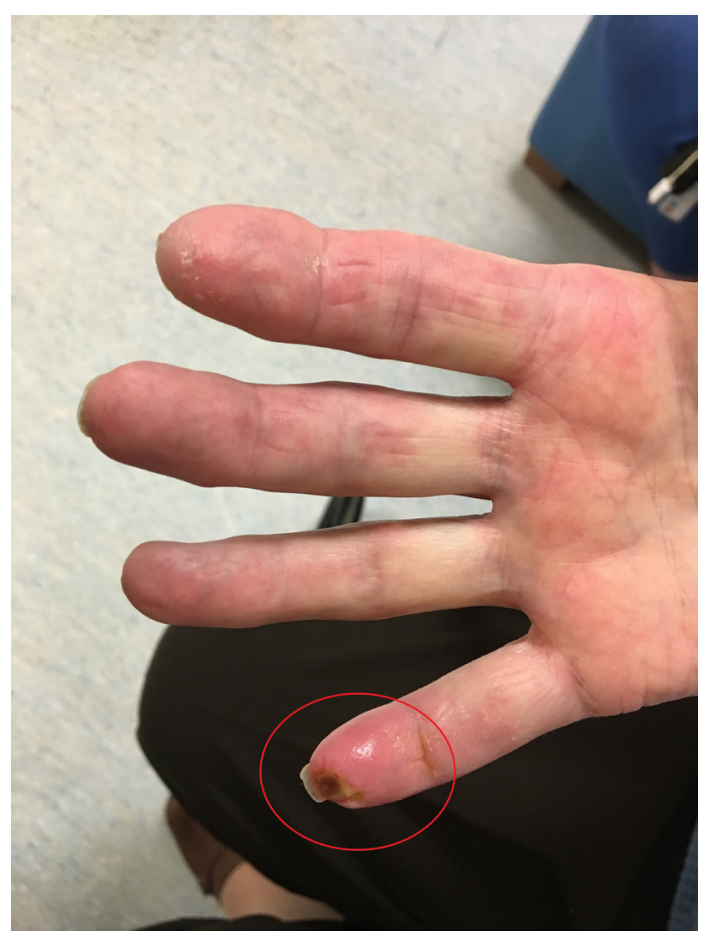

Figure 1 Right hand palmar view.

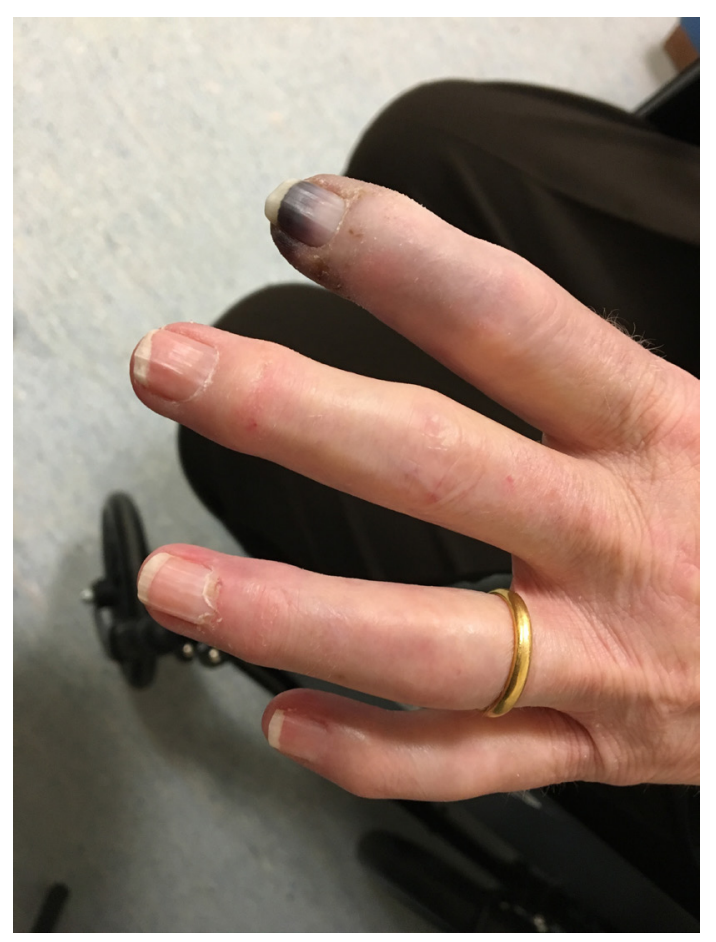

Figure 2 Left hand dorsal view.

\section{Learning points}

- Raynaud's phenomenon with digital ulceration suggests an underlying cause and warrants inpatient investigation.

- Systemic sclerosis is associated with a variety of ischaemic complications, including Raynaud's phenomenon, digital ulcers and macrovascular disease.

complications of systemic sclerosis range from mild symptoms of Raynaud's phenomenon, which are experienced by virtually all patients, to digital ulcers, irreversible tissue injury and gangrene. ${ }^{2}$ The National Institute for Health and Care Excellence advises immediate admission for severe digital ischaemia in the context of Raynaud's phenomenon. ${ }^{3}$ In elderly patients, microvascular complications should raise suspicion of macrovascular involvement. ${ }^{4}$ Overall, ischaemic complications are the primary cause of disease-related morbidity in systemic sclerosis. $^{2}$
To cite: Winstanley ME, Carmichael AC,

Harrison-Hansley E. BMJ

Case Rep 2021;14:e243452. doi:10.1136/bcr-2021-

243452 
Images in...

Acknowledgements The authors are grateful to the patient for her permission to publish and learn from these images. Unfortunately she has passed away and this piece is dedicated to her.

Contributors MEW examined and treated the patient. MEW and ACC wrote the manuscript. EHH photographed the patient and supported the publication process.

Funding The authors have not declared a specific grant for this research from any funding agency in the public, commercial or not-for-profit sectors.

Competing interests None declared.

Patient consent for publication Consent obtained from next of kin.

Provenance and peer review Not commissioned; externally peer reviewed.
ORCID ID

Martin E Winstanley http://orcid.org/0000-0002-5600-1374

\section{REFERENCES}

1 Hügle T, Schuetz P, Daikeler T, et al. Late-onset systemic sclerosis--a systematic survey of the EULAR scleroderma trials and research group database. Rheumatology 2011;50:161-5.

2 Hughes M, Allanore Y, Chung L, et al. Raynaud phenomenon and digital ulcers in systemic sclerosis. Nat Rev Rheumatol 2020;16:208-21.

3 National Institute for Clinical Excellence. Raynauds' phenomenon clinical knowledge summary 2020. Available: https://cks.nice.org.uk/raynauds-phenomenon [Accessed 17 Aug 2020].

4 Ho M, Veale D, Eastmond C, et al. Macrovascular disease and systemic sclerosis. Ann Rheum Dis 2000;59:39-43.

Copyright 2021 BMJ Publishing Group. All rights reserved. For permission to reuse any of this content visit

https://www.bmj.com/company/products-services/rights-and-licensing/permissions/

BMJ Case Report Fellows may re-use this article for personal use and teaching without any further permission.

Become a Fellow of BMJ Case Reports today and you can:

- Submit as many cases as you like

- Enjoy fast sympathetic peer review and rapid publication of accepted articles

- Access all the published articles

- Re-use any of the published material for personal use and teaching without further permission

Customer Service

If you have any further queries about your subscription, please contact our customer services team on +44 (0) 2071111105 or via email at support@bmj.com.

Visit casereports.bmj.com for more articles like this and to become a Fellow 